\title{
DYPLOMACJA OPARTA NA RELIGII - STOSUNKI DYPLOMATYCZNE CHIN Z WATYKANEM WCZORAJ I DZIŚ
}

W erze postępującej globalizacji, gdy świadomość wagi wzajemnych relacji - zarówno dyplomatycznych, jak i gospodarczych - nareszcie osiagnęła satysfakcjonujący poziom w większości krajów uznawanych za cywilizowane, coraz trudniej jest znaleźć globalnych graczy lekceważących się wzajemnie. Zmuszone ogólną sytuacją międzynarodową i naciskami światowej oraz własnej opinii publicznej Chiny i Watykan, po wielu latach napięć i wzajemnych oskarżeń, stawiają pierwsze nieśmiałe kroki na drodze ponownego nawiązania stosunków dyplomatycznych i wzajemnego pojednania.

Sytuacja ta jest szczególna, gdyż, chcąc dojść do porozumienia, obie strony musiałyby podjąć niezbędne wyrzeczenia, ustapić z dotąd zajmowanych pozycji i wiele zmienić w swojej dotychczasowej polityce, głównie religijnej, choć nie tylko. Jest to niełatwe zadanie, które od Chin wymagałoby ustapienia od głoszonych przez lata tez o szkodliwości religii, a od Watykanu zmiany stosunku do maoistów, dumnie dotąd pogardzanych. Mimo że relacje dyplomatyczne na linii Watykan - Chiny są nadzwyczaj burzliwe i pełne wzajemnych zarzutów, współczesność wymusza zmianę konserwatywnych stanowisk dotychczasowych oportunistów, szczególnie w tak delikatnej materii, jaką jest religia. Stąd też coraz bardziej aktywne działania Watykanu i Państwa Środka na drodze do ocieplenia wzajemnych relacji. Chiny muszą ostatecznie poradzić sobie ze spuścizną komunizmu, kiedy to otwarcie zwalczano wszelkie przejawy wiary chrześcijańskiej.

Napięcie pomiędzy chińskim rządem a władzami państwa Watykan utrzymuje się od 1949 r., kiedy to rządy przejęła Partia Komunistyczna i zerwała oficjalne stosunki z Watykanem ${ }^{1}$. Jednak już sam fakt, że tak trudną relację dyplomatyczną udało się kiedykolwiek ustanowić, zasługuje na uwagę badaczy. Warto również nadmienić, że proklamowana wówczas w 1949 r. Chińska Republika Ludowa nigdy nie nawiązała stosunków z Watykanem. Stosunki Chin ze Stolicą Apostolską zostały ustanowione w 1943 r., na 6 lat przed powstaniem ChRL.

1 M. Forsythe, New Bishop in China Signals Hope for Relations With Vatican, „The New York Times", 5.08.2015, http://www.nytimes.com/2015/08/06/world/asia/china-ordains-bishopjoseph-zhang-yinlin.html?_r=1 (dostęp: 6.01.2017). 
Analizując kwestie stosunków dyplomatycznych na linii Watykan - Chiny, należy mieć na względzie również fakt, że problem ten jest wciąż aktualny. Praktycznie $z$ dnia na dzień pojawiają się nowe informacje dotyczące ocieplenia relacji. Trwająca od ponad 60 lat patowa sytuacja być może już wkrótce doczeka się szczęśliwego zakończenia.

\section{Chrześcijaństwo w Chinach przed nawiązaniem stosunków dyplomatycznych z Watykanem}

Aby uzyskać pełen obraz obecnej sytuacji, szerzej spojrzeć na problem i lepiej zrozumieć poszczególne zależności, warto cofnąć się do początków chrześcijaństwa w Chinach, które, jak powszechnie wiadomo, burzliwie rozwijało się przez długie stulecia.

Pierwsze wzmianki dotyczące pojawienia się religii chrześcijańskiej w Chinach są datowane na połowę VII wieku. To właśnie wtedy mieli przybyć do Chin misjonarze - nestorianie z Persji. W związku z powyższym przyjęło się uważać, że pierwszy okres ewangelizacji Chin przypadł na lata 618-907, tzw. epokę Tang. Kolejne stulecia to kolejne etapy misji chrześcijańskich. Pierwszy kościół wybudował w Chinach włoski franciszkanin - Giovanni de Monte Corvino. To on również przygotował do chrztu ponad 6 tys. Chińczyków. Powodzenie jego misji zachęciło do przyjazdu kolejnych franciszkanów. Okres ten był zwany w historii chińskiego chrześcijaństwa franciszkańskim. Zwrot nastąpił, gdy władzę w kraju objęła dynastia Ming. Nasiliły się wówczas prześladowania tzw. obcych religii i w efekcie katolicyzm został prawie całkowicie wykorzeniony ${ }^{2}$.

Kolejna misja, która zakończyła się powodzeniem, została przeprowadzona przez o. Matteo Ricciego. Jego wielką zaletą była znajomość chińskiej tradycji i szacunek do kultury: „Ojciec Matteo starał się godzić kult przodków z chrześcijaństwem, a konfucjanizm traktował jako wstępną fazę chrześcijaństwa. (...) Gdy zmarł, cesarz, w dowód jego ogromnych zasług, polecił urządzić mu - jako pierwszemu w historii obcokrajowcowi - pogrzeb państwowy"3.

Prawdopodobnie to właśnie podejście pełne poszanowania chińskiej kultury i umiejętne wpasowanie się w wyznaczane przez tradycję ramy zachowań umożliwiło stworzenie podstaw chińskiego chrześcijaństwa. Skuteczność działań ojca Matteo była ogromna. Powołał do istnienia pięć placówek misyjnych, w których skupiało się życie religijne około 2,5 tys. katolików. Misjonarz został pochowany w 1611 r. Uważa się, że nikt tak nie przybliżył chrześcijaństwa Chinom jak on.

W latach 1622-1666 dzieło Ricciego kontynuował Adam Shall. Po jego śmierci rolę tę przejął jezuita o. Ferdynand Verbiest, który za zgodą papieża Pawła V odpra-

2 A. Zwoliński, Chiny: historia, teražniejszosíć, Kraków 2007, s. 172.

3 Ibidem, s. 174. 
wiał msze w języku chińskim. Jednak dominikanie, franciszkanie oraz augustianie oskarżali jezuitów o deformację chrześcijaństwa i krytykowali ich metody ewangelizacji. Definitywnie obrządek chiński potępił również papież Klemens XI, co potwierdził bullą Ex quo singulari z $1742 \mathrm{r}$. papież Benedykt XIV ${ }^{4}$. W efekcie spór o pojmowanie liturgii zniweczyl pracę misjonarzy i cały dotychczasowy dorobek misyjny. Chińskie władze zareagowały na napięcia dotyczące Kościoła katolickiego, zakazując misjonarzom z Zachodu wstępu do Chin, co jednak nie zniechęciło chińskich misjonarzy i kapłanów 5 .

Odrodzenie misji franciszkańskich i dominikańskich nastapiło w Chinach po kongresie wiedeńskim. W 1845 r. cesarz chiński wydał edykt, określając religię chrześcijańską jako „godną zalecenia”. Rozpoczęła się epoka chrystianizmu w Państwie Środka.

Niedługo przed nawiązaniem stosunków dyplomatycznych relacje na linii Watykan - Chiny widocznie zintensyfikowały się. W żadnym innym kraju na świecie akcja misyjna w latach 1920-1950 nie była prowadzona równie intensywnie? . W $1922 \mathrm{r}$. została utworzona delegatura apostolska. Jej przedstawicielem został C. Constantini, a 4 lata później papież Pius XI wyświęcił pierwszych sześciu biskupów chińskich. W 1939 r. również Pius XI zatwierdził „obrzędy chińskie” w encyklice Sumni Pontificatus. Oficjalnie Stolica Apostolska nawiązała stosunki dyplomatyczne z rządem chińskim w 1943 r., a Chiny otrzymały stałą hierarchię kościelną ${ }^{8}$ Jednakże wojna domowa w Chinach przyniosła zmiany na szczytach władzy. Siły komunistyczne nie planowały utrzymywać więzi ze Stolicą Apostolską.

\section{Chrześcijaństwo w Chinach po zerwaniu stosunków dyplomatycznych z Watykanem}

Po zerwaniu stosunków dyplomatycznych sytuacja gwałtownie pogorszyła się. W konsekwencji w 1951 r. nuncjatura została przeniesiona na Tajwan, z którym, notabene, Watykan utrzymuje stosunki dyplomatyczne do dnia dzisiejszego.

W grudniu 1954 r. papież Pius potępił autonomię Kościoła katolickiego w Chinach i zagroził ekskomuniką biskupów konsekrowanych bez aprobaty Watykanu. W odpowiedzi na taką zapowiedź władze chińskie poddały papieża próbie i w $1958 \mathrm{r}$. odbyła się konsekracja dwóch biskupów „oficjalnego” Kościoła. Zgodnie z przewidywaniami Watykan odmówił aprobaty tejże konsekracji. W efekcie do życia

4 Ibidem, s. $170-175$.

Ibidem, s. 175.

Ibidem, s. 176.

Por. S. Markiewicz, Kościót rąymskokatolicki a państwa socjalistyczne, Warszawa 1974.

8 A. Zwoliński, Chiny: historia..., s. 178. 
powołano Patriotyczne Zrzeszenie Katolików Chińskich (Chinese Patriotic Catholic Association) $)^{9}$. Było ono organizacją polityczną, założoną przez władze w celu kontrolowania katolickiej społeczności i działalności chińskiego Kościoła katolickiego. Formalnie rozpoczął się wtedy podział na Kościół oficjalny - chiński i podziemny watykański1 ${ }^{10}$. Za oficjalny Kościół w Chinach uważane jest Patriotyczne Zrzeszenie Katolików Chińskich mające silne związki z rządem. Biskupi Kościoła podziemnego nie są uznani przez chińskie władze. Stowarzyszenie Patriotyczne przez lata mianowało biskupów, którzy nie zostali uznani przez Rzym, zaś chiński rząd nie uznaje biskupów mianowanych przez Watykan. Rząd chiński samowolnie zlikwidował niektóre chińskie diecezje i stworzył swoją własną mapę diecezji biskupów ${ }^{11}$.

Następne dekady stanowiły kolejne etapy trudnych relacji chińsko-watykańskich. Andrzej Halimarski w swojej książce Chinska Republika Ludowa a Watykan celnie charakteryzuje poszczególne dziesięciolecia - lata 50. nazywa czasem „wzajemnej wrogości”, lata 60. to w jego opinii „okres przewartościowań”, natomiast lata 70. określa jako „nieudane próby nawiązania dialogu” ${ }^{2}$.

\section{Wzajemny brak akceptacji}

Lista tematów, których nie jest w stanie zaakceptować Watykan w polityce Chin, jest bardzo długa. Stolica Apostolska od lat niepokoi się represjonowaniem katolików w Chinach. Według hiszpańskojęzycznego biuletynu „Inforchina”, wydawanego przez Jezuicką Służbę Chinom, niemożliwe jest w obecnej sytuacji podanie dokładnej liczby katolików w Państwie Środka, niemniej szacunkowe dane pozyskane z instytucji badawczych w Hongkongu, na które powołuje się RadioVaticana, wskazuja, że w 2000 r. w Chinach było około 12 mln katolików. Kościół posiada tam 138 diecezji oraz 5 tys. kościołów i kaplic. W Chinach oficjalnie pracuje 1200 księży i 2150 zakonnic, a w podziemiu 1000 księży i 1500 zakonnic $^{13}$.

Dla Watykanu niepokojące są również kwestie dotyczące ustroju i praw człowieka. Polityka jednego dziecka, jeszcze do niedawna nadzwyczaj restrykcyjnie przestrzegana, wielokrotnie prowadziła do wymuszonych aborcji, a w skrajnych przypadkach do zabijania noworodków. Rząd i chiński Kościół popierają aborcję.

9 K. Darewicz, Jak odbudować most: Chiny - Watykan: korespondencja z Pekinu, „Rzeczpospolita”, 14-15.06.1997, s. 19.

10 Ibidem.

11 A. Gagliarducci, Much remains to be done, but Vatican-China relations may be improving, http:// www.catholicnewsagency.com/news/much-remains-to-be-done-but-vatican-china-relationsmay-be-improving-30791/ (dostęp: 2.01.2017).

12 Por. A. Halimarski, Chinska Republika Ludowa a Watykan, Warszawa 1989.

13 Ilu katolików jest obecnie w Chinach?, http://www.opoka.org.pl/aktualnosci/news.php?s=opoka\&id=742 (dostęp: 23.02.2017). 
Jednak najbardziej kontrowersyjny z pozycji Stolicy Apostolskiej i zarazem najtrudniejszy do rozstrzygnięcia jest fakt, że Kościół państwowy, kierowany przez Chińskie Katolickie Stowarzyszenie Patriotyczne kontrolowane przez władze w Chinach, nie uznaje zwierzchnictwa papieża ${ }^{14}$.

Pod adresem Watykanu Chiny również kierują wiele zarzutów i pretensji. Znaczącym problemem wydaje się zagrożenie, jakie chińskie władze upatrują w roli papieża jako zwierzchnika Kościoła katolickiego, kierując tym samym swoje obawy bezpośrednio w stronę Kościoła. Badacz stosunków chińsko-watykańskich Krzysztof Darewicz podaje dwie cechy Kościoła, przez które ówczesna władza uznała Kościół katolicki za zagrożenie. Pierwsza jest fakt, że mniej niż połowę księży i misjonarzy stanowili Chińczycy, a wśród 143 biskupów było ich jedynie 20. Druga jest poniekąd jej następstwem. „Zdominowana przez cudzoziemców hierarchia chińskiego Kościoła" sprzyjała kolonialnej ekspansji obcych mocarstw w tym kraju. Chińskie władze utożsamiały katolicki kler z ,zagranicznymi imperialistycznymi siłami, dążącymi do kolonialnej eksploatacji Chin”, a Watykan był postrzegany jako „antykomunistyczny ośrodek dyspozycyjny imperializmu" 15 .

Podobnego zdania jest ksiądz Roman Malek, który na łamach „Tygodnika Powszechnego" pisał, że Chińczycy prowadza „walkę z zachodnim imperializmem”, gdy tylko pojawia się temat "duchowego wpływu na społeczeństwo chińskie”"16. Za takowy Państwo Środka uważa mianowanie biskupów przez Watykan. W opinii chińskiego rządu jest to ingerencja w jego wewnętrzne sprawy. „Kościół katolicki w Chinach, by legalnie funkcjonować, musi wykazywać lojalność wobec partii komunistycznej. To stwarza ogromne napięcia i problemy wśród chińskich katolików, sprzyjając podziałom i oddaleniu od Watykanu"17.

Ponadto Chińczycy są przeciwni utrzymywaniu relacji Watykanu z Tajwanem. Watykan jest jednym z 23 krajów na świecie i jedynym w Europie, który uznaje państwo Tajwan. Tym samym dyplomatyczne więzi Tajwanu z Watykanem pozwoliły temu pierwszemu na liczne podróże dyplomatyczne do Europy, szczególnie w ostatnich latach. Tajwański prezydent Ma Ying-jeou uczestniczył nawet w inauguracyjnej mszy papieża Franciszka w 2013 r. Chiny oficjalnie nie były tam wówczas obecne. Z kolei na kanonizacje Jana Pawła II i Jana XXIII przybył do Watykanu wiceprezydent Wietnamu Wu Den-yih. Obie te wizyty zostały bardzo negatywnie przyjęte w ChRL ${ }^{18}$.

\footnotetext{
${ }^{14}$ Chiny chca lepsaych stosunków ₹.Watykanem, https://www.fronda.pl/a/chiny-chca-lepszych-stosunkow-z-watykanem,40655.html (dostęp: 18.01.2017).

15 K. Darewicz, Jak odbudować most..., s. 19.

16 R. Malek, Konfliket Watykan - Pekin wokót chinskich meczenników „O znaki bardziej caytelne”, „Tygodnik Powszechny" 2000, nr 47.

17 Chiny chca lepsaych stosunków...

18 S. Tiezzi, Can China and the Holy See Overcome Their Differences?, „The Diplomat”, 16.08.2014, http://thediplomat.com/2014/08/can-china-and-the-holy-see-overcome-their-differences / (dostęp: 3.02.2017).
} 
Wbrew pozorom kwestia stosunków Watykanu z Tajwanem wydaje się najłatwiejsza do rozwiązania. By zapobiec kolejnym podróżom władz Tajwanu do Watykanu, Chiny musiałyby pójść na kompromis ze Stolicą Apostolską. Watykan jest gotowy na zamrożenie stosunków z Tajwanem, aby móc ponownie nawiązać stosunki z Chinami. Jednak za ten gest będzie oczekiwać od Chin czegoś w zamian. Oczekiwania te dotyczą zarzutu Chin wobec ingerencji Watykanu. Chiny nie uznaja zwierzchnictwa papieża nad Chińskim Kościołem Katolickim, zaś Watykan brak wolności religijnej w Państwie Środka postrzega jako główną przeszkodę w pogłębianiu wzajemnych relacj ${ }^{19}$. Co więcej, oczekuje pojednania pomiędzy oboma Kościołami katolickimi, tj. chińskim rządowym i podziemnym, a to z kolei będzie wymagać od Pekinu akceptacji zgromadzenia religijnego, które znajduje się pod rządami papieskimi.

Główny problem dotyczy jednak mianowania kościelnych przywódców. Dotychczas Chiny zastrzegały sobie prawo do mianowania swoich własnych biskupów, na co Watykan nie wyraża zgody. Stolica Apostolska uważa, że przywilej ten jest całkowicie religijną kwestią i nie powinna mieć tu miejsca ingerencja lokalnych władz. Napięcie dotyczące tej kwestii trwa od 2012 r., kiedy Chiński Kościół Katolicki po raz kolejny zignorował Watykan i wyznaczył księdza, aby sprawował funkcję biskupa pomocniczego w Szanghaju.

Co ciekawe, Chiny nie są wcale jedynym krajem, który podważa prawo Watykanu do mianowania biskupów. Również Wietnam chce mieć ostateczne zdanie w tej kwestii. Watykan i Wietnam wypracowały koncyliacyjną umowę, na podstawie której wymagana jest zgoda obu krajów na mianowanie biskupa. Jednak w przypadku relacji z Chinami problem polega na tym, że każda ze stron chce mieć ostateczne zdanie ${ }^{20}$.

Powszechnie panuje przekonanie, że Watykan nie zerwie stosunków z Tajwanem, nie mając pewności, iż w zamian otrzyma religijne zwierzchnictwo. Pozostaje pytanie, czy Pekin zechce przekazać zwierzchnictwo nad $12 \mathrm{mln}$ chińskich katolików w zamian za pozbawienie Tajwanu jego ostatniego partnera dyplomatycznego w Europie.

Światowe mocarstwo, jakim jest Chińska Republika Ludowa, od lat rośnie w siłę przy jednoczesnym ograniczeniu wolności politycznych i podstawowych wartości ludności. Zadaniem Stolicy Apostolskiej jest natomiast promowanie tych wartości. Lista sprzecznych interesów nie jest wcale krótka. Pomimo impasu, widać oznaki, jakoby obie strony podejmowały działania mające przybliżyć je do sukcesu.

19 Ibidem.

20 Ibidem. 


\section{Ocieplenie stosunków}

Nawiązanie relacji z ChRL było jednym z największych niezrealizowanych planów papieża Jana Pawła II. Pragnął on możliwości powrotu chińskich katolików do Kościoła powszechnego i położenia kresu podziałom w tym kraju. Dlatego też przez lata utrzymywane były „poufne kontakty na płaszczyźnie dyplomatycznej”21. Dyplomatyczny zabieg papieża miał na celu niedopuszczenie do całkowitego wygaśnięcia tych i tak już niezwykle skomplikowanych stosunków.

O krok dalej poszedł papież Benedykt XVI, który listem pasterskim w 2007 r. wzywał do pojednania między katolikami tzw. Kościoła podziemnego i tego nieuznawanego przez Watykan ${ }^{22}$. Jednak to papież Franciszek najprawdopodobniej będzie tym, za którego urzędowania dokona się przełom. Za moment historyczny uważana jest wizyta w Stanach Zjednoczonych chińskich kapłanów (duchownych Kościoła uznawanego przez władze chińskie), która zbiegła się z wizyta papieża Franciszka. Za pośrednictwem amerykańskiego kardynała chińscy kapłani przekazali papieżowi Biblię, w której odręcznie napisali: „Kochamy Cię, modlimy się za Ciebie, czekamy na Ciebie w Chinach"'23.

Tak jak w przypadku Stolicy Apostolskiej każdy kolejny papież pracował nad polepszeniem relacji z Chinami, tak ze strony Państwa Środka o zmianie polityki religijnej zaczęto mówić zdecydowanie w 2013 r., kiedy rządy w kraju objął Xi Jinping. Od tego momentu znacznie zwiększyła się liczba informacji prasowych dotyczących możliwości ponownego nawiązania stosunków, a także oficjalnych doniesień potwierdzających wznowienie rozmów. Zarówno z Chin, jak i z Watykanu zaczęły płynąc informacje o wzajemnym szacunku i chęci ponownego porozumienia. Pierwsza bezpośrednia korespondencja pomiędzy głowami obu państw od 1949 r., a tym samym powód do ogłoszenia oficjalnego ocieplenia relacji, nastąpiła, gdy Franciszek wkrótce po objęciu stanowiska wystosował list do prezydenta ChRL Xi Jinpinga ${ }^{24}$.

W 2014 r. jeszcze bardziej zaczęły nasilać się oznaki przez wielu interpretowane jako zwiastun poprawy stosunków pomiędzy ChRL a Stolicą Apostolską. Jednym z bardziej charakterystycznych sygnałów ocieplenia relacji na linii Watykan - Chiny była opisywana w światowych mediach pozytywna odpowiedź przewodniczącego

${ }^{21}$ K. Darewicz, Jak odbudować most..., s. 19.

22 List Ojca Świętego Benedykta XVI do Biskupów, do Kapłanów, do Osób Konsekrowanych oraz do Wiernych Świeckich Kościoła katolickiego w Chińskiej Republice Ludowej, dostępny na stronie: http://w2.vatican.va/content/benedict-xvi/pl/letters/2007/documents/hf_ben-xvi_ let_20070527_china.html (dostęp: 20.02.2017).

${ }^{23} J u \dot{z}$ niebawem Watykan nawiqże stosunki dyplomatyczne z Pekinem?, http://www.pch24.pl/juzniebawem-watykan-nawiaze-stosunki-dyplomatyczne-z-pekinem-,42233,i.html (dostęp: 8.02.2017).

${ }^{24}$ Ibidem. 
ChRL Xi Jinpinga na prośbę wystosowana przez papieża Franciszka, dotycząca przejścia przez chińską strefę powietrzną podczas podróży apostolskiej z Korei Południowej do Rzymu. Była to pierwsza wizyta w tym rejonie głowy Kościoła katolickiego od czasów, gdy Jan Paweł II odwiedził Filipiny w 1995 r.

W protokole dyplomatycznym Watykanu istnieje zwyczaj, według którego papież wysyła pozdrowienia kurtuazyjne dla przywódców i narodu na ręce lidera każdego państwa, nad którym przelatuje bądź przez które przejeżdża. Krótka wiadomość do Xi, a także fakt, że udzielono papieżowi zgody na przelot przez chińską strefą powietrzna, rozpoczą ożywione dyskusje na temat ponownego nawiązania relacji. Moment ten przez wielu badaczy relacji chińsko-watykańskich został uznany za przełom, który może doprowadzić do ponownego nawiązania stosunków. Jest to również niepodważalny dowód na znaczenie narzędzi dyplomatycznych, które służą nie tylko nawiązywaniu i utrzymywaniu stosunków, ale są także niezbędne w czasie kryzysu bilateralnego. Odpowiednio dobrane metody komunikacji i przestrzeganie zasad narzuconych przez protokół dyplomatyczny umożliwiają przełamanie impasu również stronom, które z różnych względów nie utrzymują relacji dyplomatycznych.

Za kolejny dowód zmiany polityki religijnej w Chinach uważa się słowa rzecznika ministra spraw zagranicznych Hua Chunyinga, który kilka miesięcy po tym wydarzeniu (21 stycznia 2015 r.) ogłosił, jakoby rząd chiński pragnął prowadzić z Watykanem konstruktywny dialog oraz zapewnił, że Chiny zawsze szczerze podchodzą do umocnienia więzi łączących je z Watykanem, dokonując wszelkich starań, aby jak najszybciej ponownie doszło do dyplomatycznego porozumienia ${ }^{25}$.

Na kanwie polepszenia stosunków dokonywały się kolejne przełomy. W 2015 r. katolicy w Chinach (Hongkong) konsekrowali pierwszego nowego biskupa od 3 lat, co można definiować jako kolejną oznakę ocieplenia na linii Watykan - Pekin. Chińskie Patriotyczne Stowarzyszenie Katolickie z ramienia rządu zawiaduje Kościołami katolickimi w Chinach, powołując księży i biskupów. Spośród 12 mln katolików wielu nie akceptuje tego, że ateistyczny rząd kontroluje ich Kościół. W ostatnich latach Watykan ekskomunikował co najmniej dwóch biskupów konsekrowanych przez chiński Kościół, którzy nie otrzymali poparcia papieża. Konsekracja biskupa Zhanga jest więc sygnałem na ciche przyzwolenie, że oficjalny Kościół będzie powoływać tylko tych biskupów, którzy mają zgodę Watykanu. Biskup Zhang zgodę taką otrzymał ${ }^{26}$.

\section{Perspektywy nawiązania oficjalnych relacji}

Wielu badaczy zastanawia się, czy możliwe jest osiagnięcie kompromisu, który pozwoli na ponowne ustanowienie formalnych stosunków dyplomatycznych. Pewne

25 A. Gagliarducci, Much remains to be done...

26 M. Forsythe, New Bishop in China... 
jest natomiast, że aby mogło nastapić oficjalne przywrócenie relacji, na które wszyscy czekają, oba kraje muszą spełnić wiele bezwzględnych warunków.

Stolica Apostolska oczekuje ustępstw ze strony prezydenta Chin Xi Jinpinga w kwestii dotyczącej uznania roli papieża w zatwierdzaniu lokalnych biskupów. Chiny jednak pragną utrzymać patriotyczny Kościół, podporządkowany rządowi.

Co ciekawe, Watykan ma swoich sojuszników również w samym stowarzyszeniu. Patriotyczne Zrzeszenie Katolików Chińskich - kontrolowane przez rząd - popiera wysiłki papieża Franciszka i rozpoczęło lobbing na rzecz ustanowienia oficjalnych relacji pomiędzy Chinami a Stolicą Apostolskąa

Ustanowienie dyplomatycznych relacji z Chinami i Wietnamem było celem papieża Jana Pawła II, a następnie papieża Benedykta XVI. Obecnie nad ponownym nawiązaniem kontaktów dyplomatycznych pracuje papież Franciszek. Sytuacja jest niezwykle dynamiczna. Być może kwestia, która do tej pory uchodziła za najbardziej problematyczna, zostanie rozwiązana w pierwszej kolejności. Wszystko wskazuje na to, że kompromis, który obie strony od lat próbują wypracować, będzie ostatecznie polegać na wspólnym wyborze biskupów. Niektóre źródła podają że pomiędzy papieżem Franciszkiem a prezydentem Xi Jinpingiem jest prowadzona wymiana korespondencji.

Kardynał John Tong Hon, głowa Kościoła w Hongkongu, uznawany przez Rzym, przyznał, że Pekin i Watykan osiagnęły konsensus w jednym z aspektów. Według najnowszych doniesień został rozwiązany najbardziej kontrowersyjny problem - mianowanie biskupów. Według katolickiej doktryny to papież jest najwyższą władza mianująca biskupów. Skoro zatem ostatnie zdanie należy do papieża, wybory w lokalnych Kościołach i rekomendacje Konferencji Biskupów Katolickiego Kościoła w Chinach (the Bishop's Conference of the Catholic Church in China) będą niczym innym, jak sposobem przedstawienia propozycji. $\mathrm{Na}$ takie rozwiązanie przystały obie strony.

Warto pamiętać, że dla Chin najważniejsze jest zachowanie nadrzędnych wartości, takich jak patriotyzm i lojalność w stosunku do państwa. Mimo że polityczna liberalizacja Chin następuje dość wolno, to ostatnia dekada obfituje w znaczące polityczne i ekonomiczne zmiany ${ }^{28}$, co pozwala mieć nadzieję na wypracowanie kompromisu również w tych kwestiach, które w dalszym ciagu pozostają nieuregulowane.

W Chinach znajduje się obecnie 30 biskupów nieakceptowanych przez Rzym oraz 7 takich, których nie akceptuje ani Rzym, ani Pekin ${ }^{29}$. Aby doszło do porozumienia, również ten problem musi zostać rozwiązany.

27 Jùं niebawem Watykan...

28 J. Melissen, The New Public Diplomacy. Soft Power in International Relations, Hampshire 2005, s. 89.

29 C. Wang, China and the Vatican Are a Step Closer to Mending Ties, „The Diplomat”, 10.02.2017, http:/ / thediplomat.com/2017/02/china-and-the-vatican-are-a-step-closer-to-mendingties/?utm_content=bufferfe316\&utm_medium $=$ social\&utm_source=twitter.com\&utm_campaign=buffer (dostęp: 22.02.2017). 


\section{SUMMARY}

\section{RELIGIOUS DIPLOMACY: CHINA AND VATICAN (NOW AND THEN)}

China, after years of an international isolation, begins to play a more extensive role in the world. It becomes the main world player in every branch of a single nation's activity, starting from economy through military to social and culture areas. One of the probes of the international rebirth of this great nation is its diplomatic relations with Vatican. The reason diplomatic relations with the state of Vatican were for some time out of discussion was the Chinese ideology. After it was abandoned, it appeared there are only two issues implicating those relations: Vatican's diplomatic relations with Taiwan and the Chinese Catholic Church's wish to remain independent from the Pope.

The last few years show the meaningful change of the Chinese and Vatican's approach to the problem: it appears that the, so called, border issues are defined. Vatican expects China to acknowledge the Pope as the head of the universal Church, whereas Vatican is supposed to revise its diplomatic relations with Taiwan - Vatican is now the only state in Europe to maintain the diplomatic links with Taiwan. In the research, the author has traced back the tangled relationship between the Holy See and the Middle Kingdom starting with the first footprints of Christianity in China to the current situation, when the significant thaw in bilateral relations takes place. Concluding, the article shows the signs of the real reestablishing of diplomatic relations between those two very specific states. 